Research Article

\title{
Experimental Study on Deformation Mechanism of a Utility Tunnel in a Ground Fissure Area
}

\author{
Dan Zhang, ${ }^{1}$ Zhiping Hu $\mathbb{D}^{1,}{ }^{1,2}$ Ganggang Lu, ${ }^{1}$ Rui Wang $\mathbb{D},{ }^{1}$ and Xiang Ren ${ }^{1}$ \\ ${ }^{1}$ School of Civil Engineering, Chang'an University, Xi'an 710061, China \\ ${ }^{2}$ Institute of Underground Structure and Engineering, Chang'an University, Xi'an 710061, China \\ Correspondence should be addressed to Zhiping Hu; huzhping@chd.edu.cn
}

Received 8 September 2019; Revised 2 February 2020; Accepted 28 February 2020; Published 13 May 2020

Academic Editor: Fuat Kara

Copyright (c) 2020 Dan Zhang et al. This is an open access article distributed under the Creative Commons Attribution License, which permits unrestricted use, distribution, and reproduction in any medium, provided the original work is properly cited.

This paper discusses the deformation mechanism of a utility tunnel crossing active ground fissures in Xi'an as observed in a physical model test. The purpose of this work is to confirm the precise effects of ground fissures on utility tunnels. The physical simulation experiment is carried out to measure the earth pressure and the strain relationship of the structure and the structural displacement. The structure appears to have been destroyed by torsion. The structural deformation located in the tunnel's footwall was more serious than that in the hanging wall. However, at the top of the utility tunnel structure, the earth pressure in the footwall was less than that in the hanging wall. The increased range of the hanging wall at $0.3-1.5 \mathrm{~m}$ (the prototype within the range of $22.5 \mathrm{~m}$ ) and decreased range of the footwall at $0.3-0.8 \mathrm{~m}$ (the prototype within the range of $12 \mathrm{~m}$ ) were basically consistent with changes in the contact pressure at the structure's bottom. This was roughly consistent with the main deformation zone of ground fissures mentioned in the specification, with the hanging wall at $0-20 \mathrm{~m}$ and footwall at $0-12 \mathrm{~mm}$. Displacement meter data shows that the structure tends to deform to the lower right as the utility tunnel is "twisted" clockwise. These observations mark a notable departure from the previously published failure mode of metro tunnels under active ground fissures.

\section{Introduction}

The ground fissure is a serious geological hazard which is common in many countries. Ground fissures were first discovered at the Goose Greek Oil Field near Houston, Texas, USA, in the 1920s. By the end of the 1950s, ground fissures were identified in China [1-9]. Ground fissures may become geological disasters that threaten the roads, buildings, and pipelines surrounding them. Throughout Shandong, Anhui, Jiangsu, Shanxi, Shaanxi, and Henan provinces, active ground fissures are a crucial consideration in effective city planning [10-21].

Ground fissures form based on the development of the nearby fault structure and the excessive exploitation of groundwater $[7,13,18]$. The excessive extraction of groundwater since the 1950s has produced fourteen ground fissures in the city of Xi' an $[3,16]$. The appearance of ground fissures, resulting in the destruction of many surface buildings and underground construction facilities, has so far caused billions of direct economic losses in Xi'an. Existing ground fissures continue to develop as new ground fissures appear, which severely restrict the effective use of urban construction land in Xi'an and the construction of new urban projects $[3,16,22,23]$.

Ground fissures in Xi'an typically undergo normal faulttype peristaltic movement wherein the hanging wall slides relative to the footwall; the vertical displacement typically shows unidirectional accumulation. Ground fissures activity profile characteristics of the city of Xi'an are shown in Figure 1 . The ground fissure tends to the south at a steep dip angle, generally above $70^{\circ}$. The ground fissure zone features three-dimensional spatial movement comprised of vertical displacement, horizontal displacement caused by northsouth tension, and horizontal dislocation at a ratio of 1 : $0.31: 0.03$. When a structure obliquely crosses the ground fissure, the activity of the ground fissure generates threedimensional spatial displacement motion in the structure, that is, vertical, transverse, and axial displacement occurring 


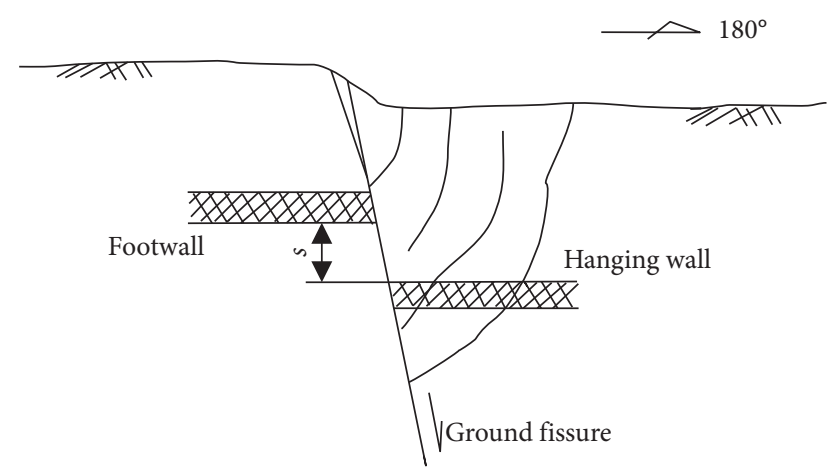

Figure 1: Movement of ground fissure.

simultaneously. The tensile displacement of ground fissures in Xi'an is generally under $10 \mathrm{~m}$ and the fissures are nearly closed, while the buried depth of utility tunnels in the area is generally less than $10 \mathrm{~m}$. Utility tunnels crossing the ground fissure zone in Xi'an are designed without considering the effects of tensile and torsional ground fissure components on the structure-only the effect of the vertical displacement is taken into account.

To quantitatively evaluate the impact of the formation and development of ground fissures on the stress field distribution of surrounding soil and building deformation under stress, researchers in related fields have performed many studies in the past few years and large-scale physical model tests have been effective research methods. Peng et al. [24], Huang et al. [25], Fan et al. [26], and Hu et al. [27] have conducted extensive physical model tests of metro tunnels passing through ground fissure zones. Existing research results have systematically revealed the causes and characteristics of ground fissures and their effects on underground structures, especially subway tunnels, but research on the effects of deformation and failure characteristics of utility tunnels across ground fissures has been still relatively rare.

Although utility tunnels and subway tunnels are both underground structures, the buried depths and structural cross sections are different. Most subway tunnels are one cabin, and a utility tunnel is basically more than two cabins, and the resulting structural section is thus more complicated. Previous studies have shown that the smaller the horizontal angle between the long-line underground structure and the ground fissures, the more the influence of ground fissures motion. As ground fissures in the city of Xi' an are basically distributed in parallel along the northeastsouthwest direction, they form a $45^{\circ}$ angle with existing planned utility tunnels (Figure 2). Therefore, this study addresses the Xi'an utility tunnel construction PPP project I bid-section of the Yanta District Kechuang Road utility tunnel project as the research background, according to its geological survey report, combined with existing ground fissure survey results. Research data speculates that the Xi' an ground fissure $f_{6}$ develops on the east side of the construction site. This study intended to carry out a physical model test on the deformation and failure mode of the utility tunnel with a $45^{\circ}$ oblique penetration of the ground fissure. The model test was designed with a geometrical scale

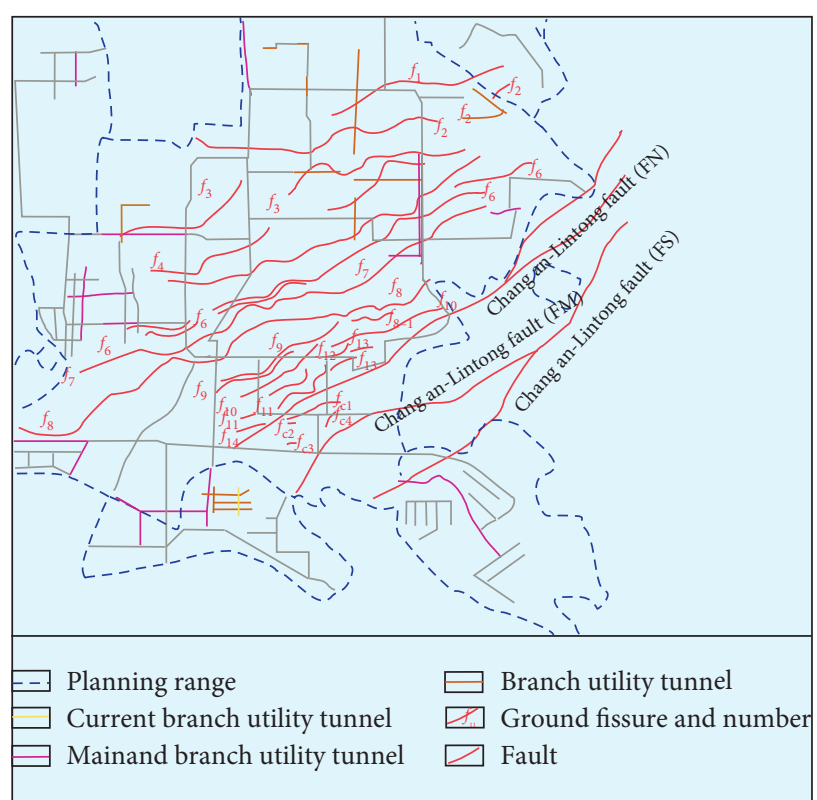

FIgURE 2: Xi'an underground utility tunnel plaining and ground fissure distribution map.

of $1: 15$. Based on the analysis of structural strain, earth pressure, and structural displacement under the active ground fissure zone, the deformation modes of the utility tunnel structure were summarized. It was anticipated here to supply a certain reference for the design and construction of a utility tunnel projecting through a ground fissure zone.

\section{Model Test}

2.1. Physical Model Test Equipment. Figure 3 is the physical model test equipment applied in this study. The testing equipment has dimensions of $5.0 \mathrm{~m}$ length, $2.5 \mathrm{~m}$ width, and $2.5 \mathrm{~m}$ height. The hanging wall descends relative to the footwall; the footwall is stable (Figure 1). To simulate the temporal effects of ground fissures, the equipment was equipped with self-locking jacks to slowly descend. The settlement of the hanging wall in this model test was $80 \mathrm{~mm}$ and was applied in eight stages. The inclination of the ground fissure in the experiment was 80 degrees (Figure 3). Strain gauges were used to test the mechanical deformation and earth pressure cells were used to test the earth pressure under the displacement of the ground fissure. The test principle is shown in Figure 3.

2.2. Model Test Similar Ratio. According to the similarity principle [28], the geometry similarity ratio $C_{L}=15$, and the concrete elastic modulus similar constant $C_{E_{c}}=4$; a similar relationship between other physical quantities can be established as shown in Table 1. The model utility tunnel cross section is shown in Figure 4.

2.3. Model Similar Material. In this test, the surrounding soil used loess-like soil; soil material parameter values include the following: 


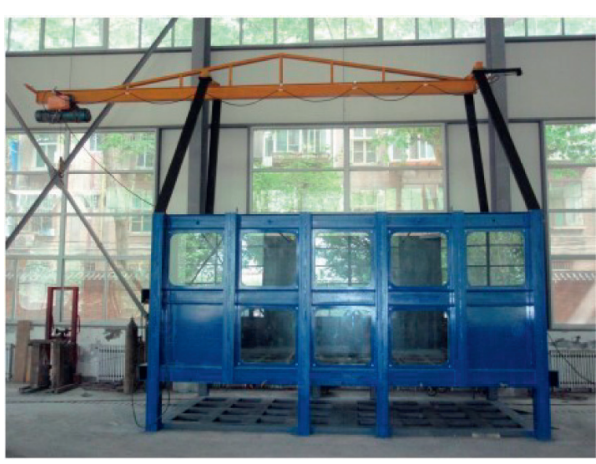

(a)

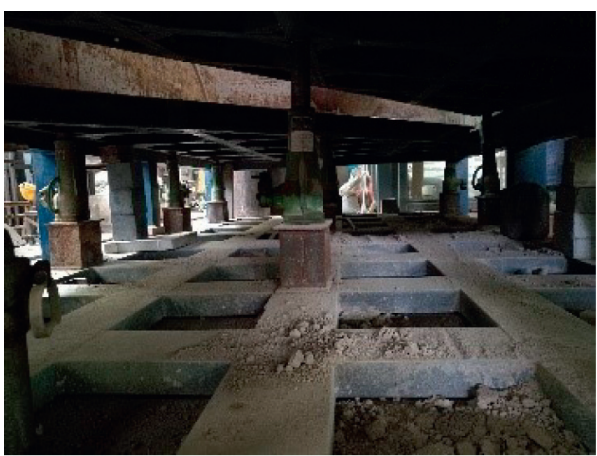

(b)

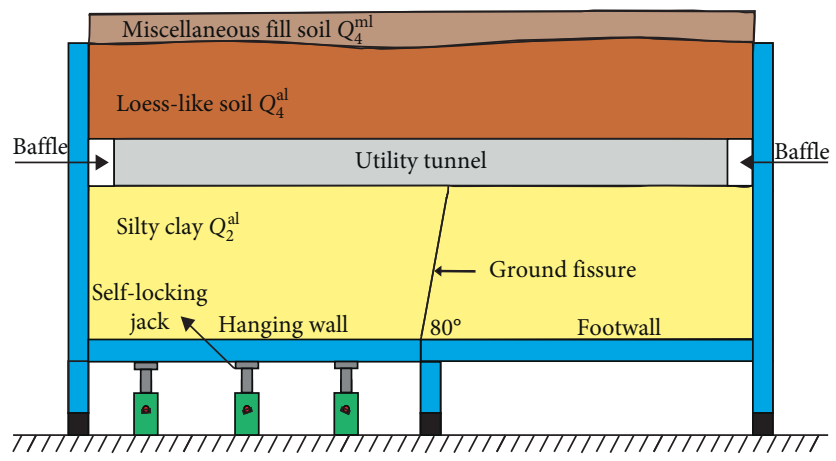

(c)

Figure 3: Model box. (a) Test model box picture. (b) Picture of self-locking jack. (c) Test model box schematic.

TABLE 1: Similarity ratio of model test.

\begin{tabular}{|c|c|c|}
\hline Types & Physical quantity & Similarity constant (not completely similar) \\
\hline Material properties & $\begin{array}{c}\text { Concrete stress } \sigma_{c} \\
\text { Rebar strain } \varepsilon_{s} \text {, concrete strain } \varepsilon_{c} \\
\text { Concrete elastic modulus } E_{c} \\
\text { Rebar stress } \sigma_{s} \\
\text { Reinforced elastic modulus } E_{s}\end{array}$ & $\begin{array}{c}C_{\sigma_{c}}=C_{\sigma}=4 \\
C_{\varepsilon_{s}}=C_{\varepsilon_{c}}=C_{\varepsilon}=1 \\
C_{\varepsilon_{s}}=C_{\varepsilon_{c}}=C_{\varepsilon}=4 \\
C_{\sigma_{s}}=1 \\
C_{E_{s}}=1\end{array}$ \\
\hline Geometric characteristics & $\begin{array}{c}\text { Line displacement } x \\
\text { Angular displacement } \theta \\
\text { Reinforcing area } A_{s}\end{array}$ & $\begin{array}{c}C_{x}=C_{\varepsilon} C_{l}=15 \\
C_{\theta}=C_{\varepsilon}=1 \\
C_{A s}=C_{\sigma} C_{l}^{2} / C_{\varepsilon}=900\end{array}$ \\
\hline Loading & $\begin{array}{l}\text { Concentration } F \\
\text { Line load } q \\
\text { Surface load } p \\
\text { Torque } M\end{array}$ & $\begin{array}{c}C_{F}=C_{\sigma} C_{l}^{2}=900 \\
C_{q}=C_{\sigma} C_{l}=60 \\
C_{p}=C_{\sigma}=5 \\
C_{M}=C_{\sigma} C_{l}^{3}=13500\end{array}$ \\
\hline
\end{tabular}

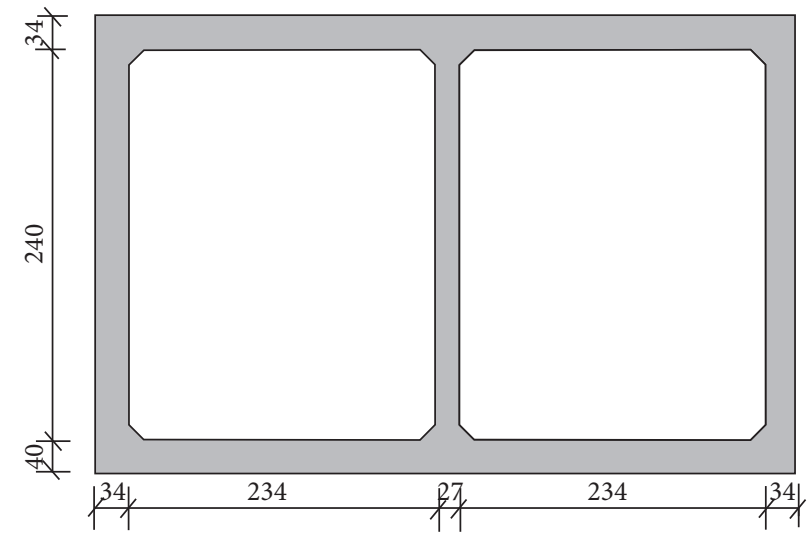

Figure 4: Model utility tunnel cross section (mm). 
$\gamma=18.6 \mathrm{kN} / \mathrm{m}^{3} \gamma$-soil bulk density

$E=9 \mathrm{MPa} E-$ modulus of elasticity

$\nu=0.35 \nu$-Poisson' ratio

$C=0.025 C$-cohesion

$\varphi=24 \varphi$-internal friction angle

The model concrete was cast from fine aggregate concrete with a certain amount of steel mesh inside. The model utility tunnel was fabricated from fine aggregate concrete. The parameters determined according to a series of multiple ratio tests prior to testing are shown in Table 2 . The mix ratio of the model's fine aggregate concrete is shown in Table 3.

The rebar (short for reinforcing bar) rate of the structure is determined by the principle of equal strength, as shown in the following formula:

$$
\frac{A_{p s} \cdot f_{p y}}{A_{p c} \cdot f_{p c}}=\frac{A_{m s} \cdot f_{m y}}{A_{m c} \cdot f_{m c}}
$$

where $A_{p s}$ and $A_{p c}$ are prototype reinforcement and concrete area. $f_{p y}$ is tensile strength of prototype reinforcement. $f_{p c}$ is compressive strength of prototype concrete. $A_{m s}$ and $A_{m c}$ are model reinforcement and concrete area. $f_{m y}$ is tensile strength of model reinforcement. $f_{m c}$ is compressive strength of model concrete.

The dip angle of the ground fissure is $80^{\circ}$ according to the measurements taken during the ground fissure simulation with fine sand.

2.4. Test Contents and Data Collection. The rows of $45^{\circ}$ strain flowers were arranged at the top, bottom, and sides of the model with nine flowers in each row to measure strain in different directions of the utility tunnel lining. A layout of the measurement points is shown in Figure 5.

At the intersection of the structural axis and the ground fissure, which is $0.25 \mathrm{~m}$ on each side, strain gauges were arranged on stirrups on three sections, which were used to test the circular strain of the structural steel. The section located the axial midpoint of the structure (Figure 6).

Ten sections were arranged along the axial direction of the structural steel with eight measuring points on each section to measure the longitudinal strain of reinforcement at the top and bottom of the structure (Figure 7).

A total of eight measuring lines were arranged along the axial direction of the structure-three at the top and five at the bottom-to test the changes in longitudinal earth pressure during the experiment. Five sections were arranged perpendicular to the axis of the structure with two measuring lines each. The top and bottom of the structure were equipped with five measuring lines to determine changes in transverse earth pressure during the experiment. One measuring line was arranged on the north and south sides of the structure. Each measuring line was equipped with seven earth pressure boxes to test the changes in earth pressure at the sides of the structure (Figure 8). All earth pressure boxes were placed $10 \mathrm{~cm}$ from the surface of utility tunnel. A total of 98 earth pressure boxes were used to test the earth
TABle 2: Model concrete parameters.

\begin{tabular}{lcc}
\hline $\begin{array}{l}\text { Unit weight } \\
\left(\mathrm{kN} \cdot \mathrm{m}^{3}\right)\end{array}$ & $\begin{array}{c}\text { Cube strength } \\
(\mathrm{MPa})\end{array}$ & $\begin{array}{c}\text { Elasticity modulus } \\
(\mathrm{MPa})\end{array}$ \\
\hline 25.00 & 5.76 & $8.41 \times 10^{3}$ \\
\hline
\end{tabular}

TABLE 3: Mix ratio of model fine aggregate concrete.

\begin{tabular}{lc}
\hline Material & Mix ratio \% \\
\hline Concrete & 1.000 \\
Fil ash & 0.43 \\
Sand & 6.59 \\
Fine gravel $(3-5 \mathrm{~mm})$ & 4.40 \\
Early strength agent & 0.030 \\
Water & 0.9 \\
\hline
\end{tabular}

pressure under the action of different values of vertical dislocation $s(s=9,19,30,40,50,60,70$, and $80 \mathrm{~mm})$.

The differential settlement displacement of the model structure was measured with displacement meters. At the intersection of the structure and the ground fissure, which is $0.08 \mathrm{~m}$ on each side, a total of three measuring sections and 24 displacement meters are used to measure the differential settlement of the utility tunnel structure (Figure 9).

\section{Test Results and Analysis}

\subsection{Earth Pressure}

3.1.1. Longitudinal Earth Pressure Variations. As shown in Figure 10(a), the vertical contact with the earth pressure along the bottom of the utility tunnel was mainly manifested by a small amount of change in the hanging wall when the vertical settlement of the ground fissure increased; however, the footwall position markedly changed during this process. The earth pressure reached its maximum value at $0.8 \mathrm{~m}$ from the footwall to the preset ground fissure and decreased as settlement increased. This may have been due to the emergence of the void area, where the section of the utility tunnel located in the footwall warped. With increased displacement level, the earth pressure on the hanging wall, except for the structure end, decreased significantly to 0 . This was roughly consistent with the scope of the void area at the structure's bottom, which was observed at the test site. The soil pressure of the footwall increased significantly, and the range of the hanging wall soil pressure decreased to 0 at 0 to $0.8 \mathrm{~m}$ (actual prototype hanging wall at $12 \mathrm{~m}$ ). The footwall earth pressure increased within the range of $0-0.8 \mathrm{~m}$ (actual prototype lower plate at $12 \mathrm{~m}$ ). At the $0.8 \mathrm{~m}$ measuring point of the hanging wall, when the settlement $s$ was from 3 to $4 \mathrm{~cm}$, the contact earth pressure was reduced to 0 , which indicated that a void area had begun to appear at the bottom of the structure at this time.

As shown in Figure 10(b), the top of the utility tunnel earth pressure increased significantly on the hanging wall. The earth pressure decreased near the ground fissure at the top of utility tunnel; however, there was little change as the settlement increased. The earth pressure on both sides of the ground fissure decreased as settlement increased, which may 


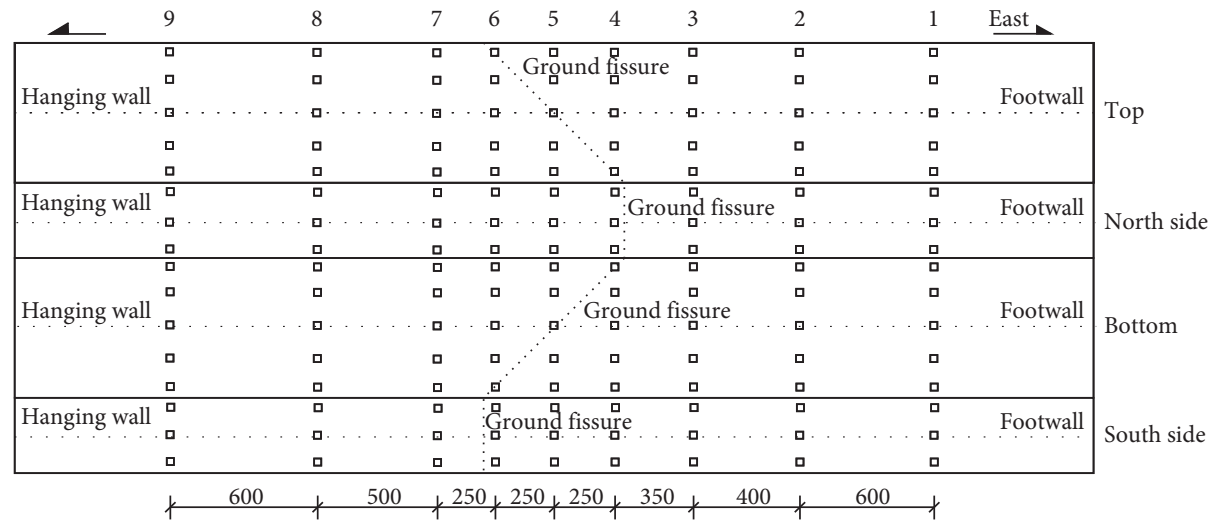

(a)

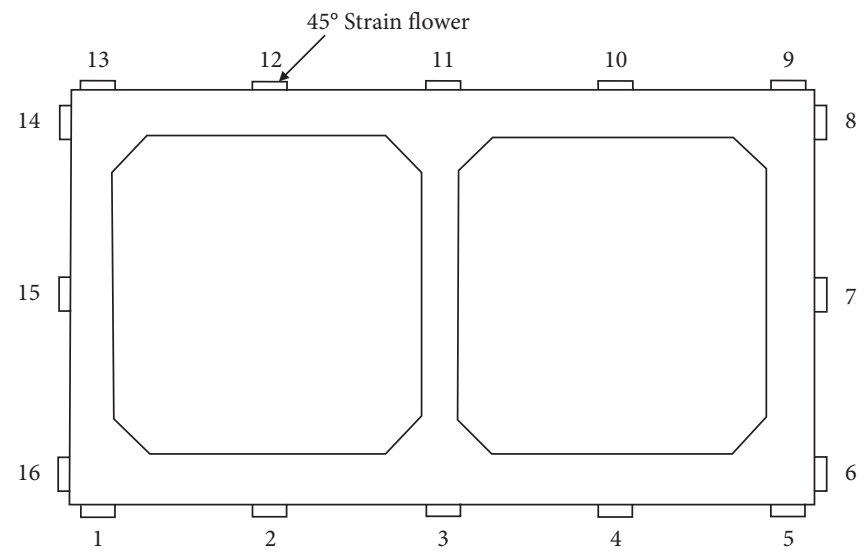

(b)

FIgURE 5: Structural strain flower arrangement (cm). (a) Position of structural strain flowers (cm). (b) Cross-sectional strain flowers layout diagram.

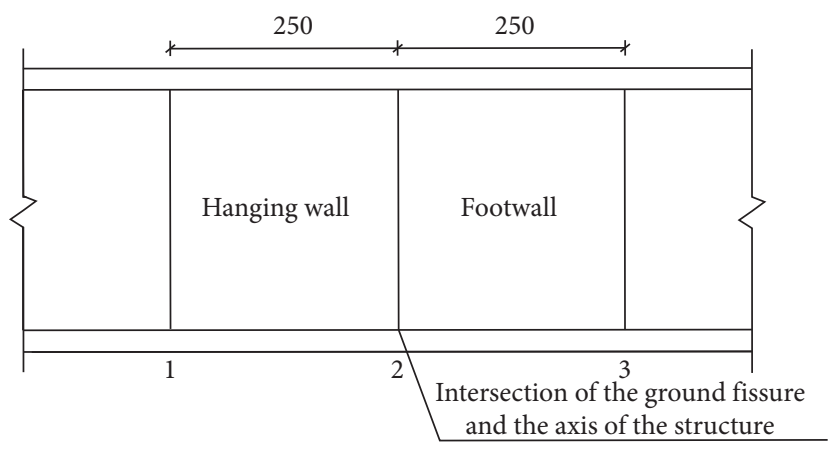

(a)

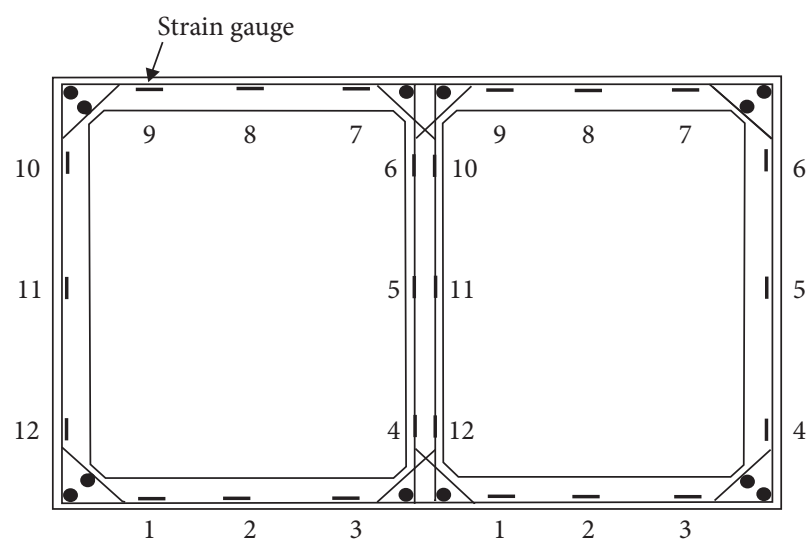

(b)

FIGURE 6: Reinforcement ring strain gauge layout (cm). (a) Position of strain gauges on stirrups (cm). (b) Stirrup cross-sectional strain gauge layout diagram.

be attributable to the influence of the void area. With increased $s$, the top contact earth pressure showed a significant increase at the hanging wall and significant decrease at the footwall. The increased range of the hanging wall at $0.3-1.5 \mathrm{~m}$ (the prototype within the range of $22.5 \mathrm{~m}$ ) and decreased range of the footwall at $0.3-0.8 \mathrm{~m}$ (the prototype within the range of $12 \mathrm{~m}$ ) were basically consistent with changes in the contact pressure at the structure's bottom. This was roughly consistent with the main deformation zone of ground fissures mentioned in the specification, with the hanging wall at $0-20 \mathrm{~m}$ and footwall at $0-12 \mathrm{~mm}$ [29]. When the settlement was increased from 9 to $19 \mathrm{~mm}$, the earth 


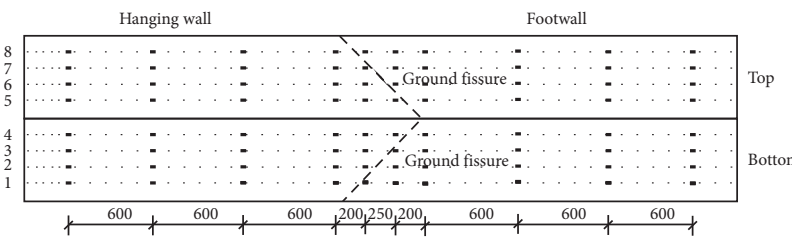

(a)

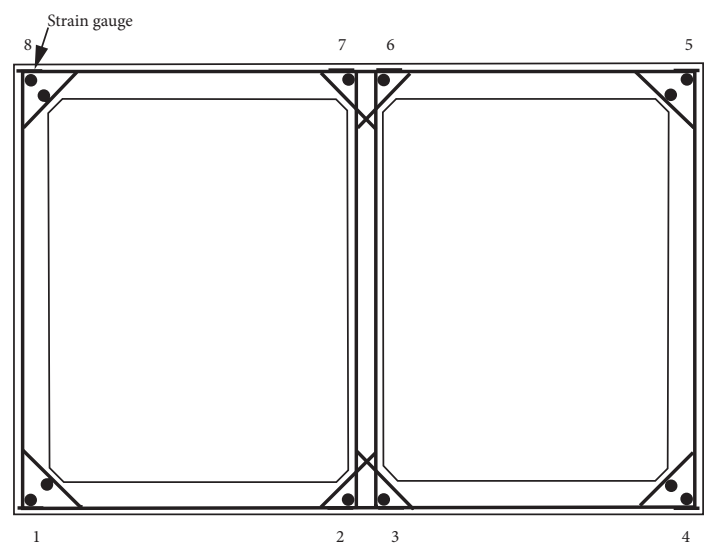

(b)

Figure 7: Structural longitudinal reinforcement strain gauge layout $(\mathrm{cm})$. (a) Position of longitudinal rebar strain gauges ( $\mathrm{cm}$ ). (b) Longitudinal rebar section strain gauges layout diagram.
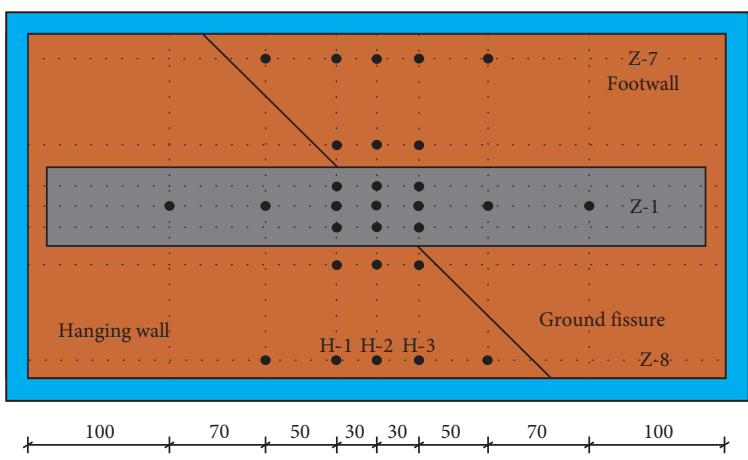

(a)

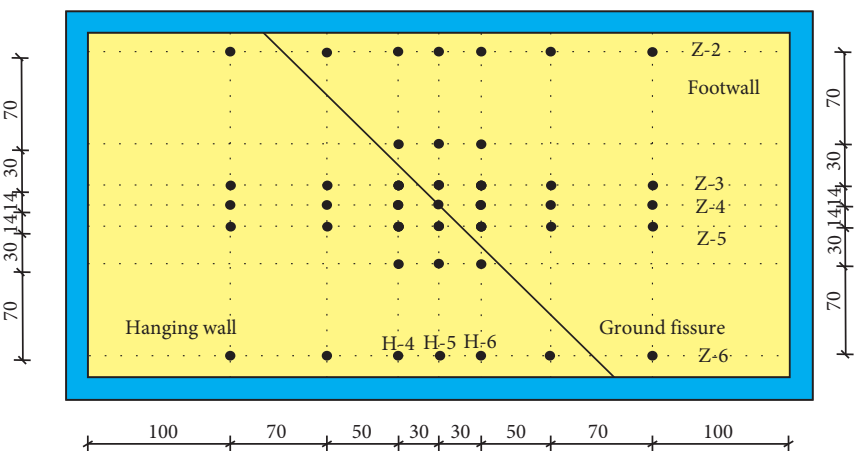

(b)

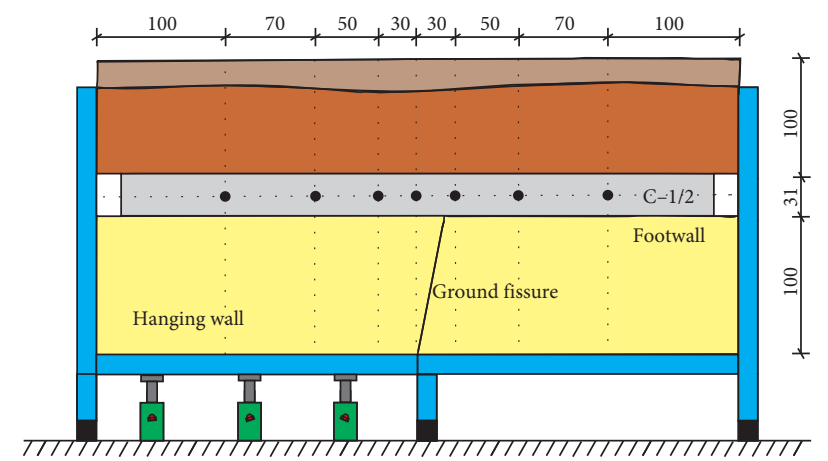

(c)

FiguRE 8: Earth pressure box layout (cm). (a) Top earth pressure box layout (cm). (b) Bottom earth pressure box layout (cm). (c) Layout of earth pressure box on the left and right side of the structure $(\mathrm{cm})$.

pressure at the structure's top changed greatly, indicating that the structure was relatively stressed during this process.

\subsubsection{Transverse Earth Pressure Variations. Transverse earth} pressure variations on the top of the structure are shown in Figure 11. In Figure 11(a), this section is located from the intersection of the ground fissure and the axis of the utility tunnel structure to the hanging wall at $0.8 \mathrm{~m}$. On the footwall, the earth pressure decreased as ground fissure vertical displacement increased. On the hanging wall, the earth pressure increased as ground fissure vertical displacement increased, forming a clockwise torque or "twist." The position of the axis at the top of the structure bore the maximum earth pressure, but the earth pressure on both sides decreased. The twisting also loosened the soil on both sides of the structure.

In Figure 11(b), the section located from the intersection of the ground fissure and the axis of the utility tunnel 


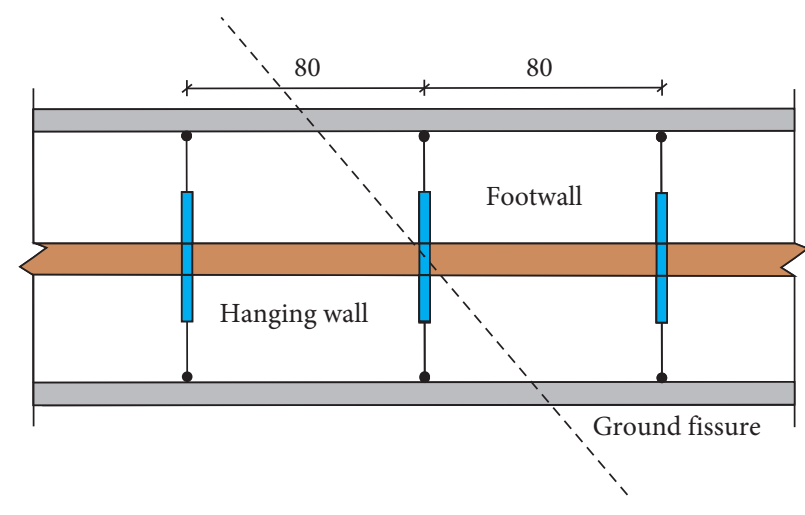

(a)

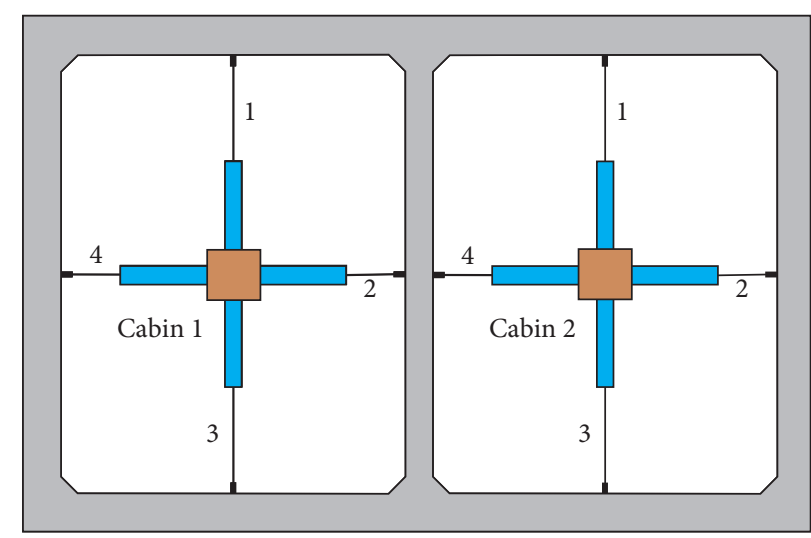

(b)

Figure 9: Schematic diagram of displacement meter arrangement $(\mathrm{cm})$. (a) Position of displacement meter (cm). (b) Structure crosssectional displacement meter layout diagram.

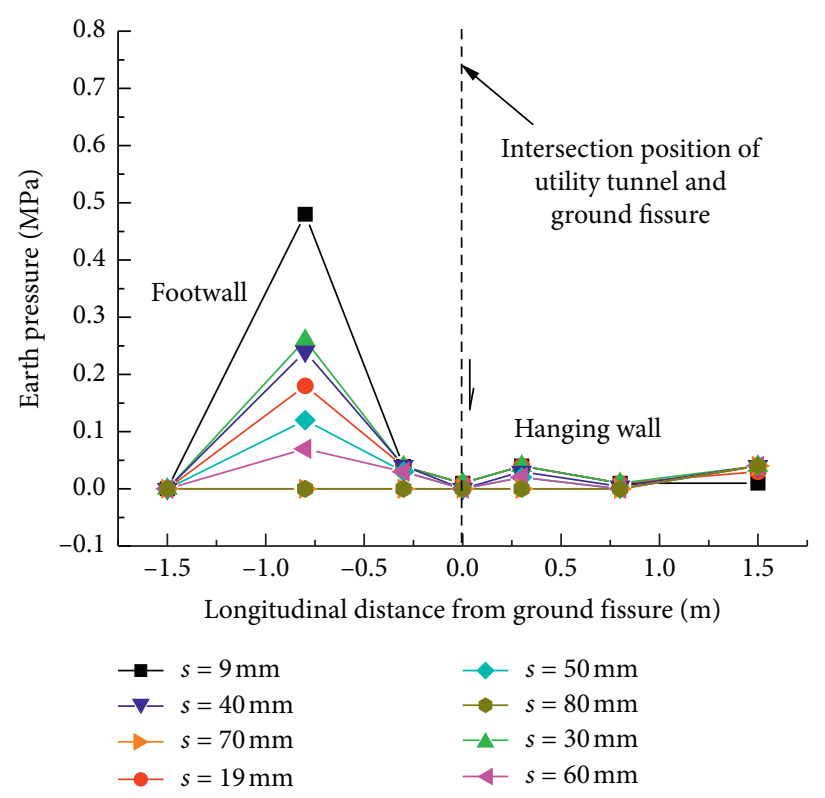

(a)

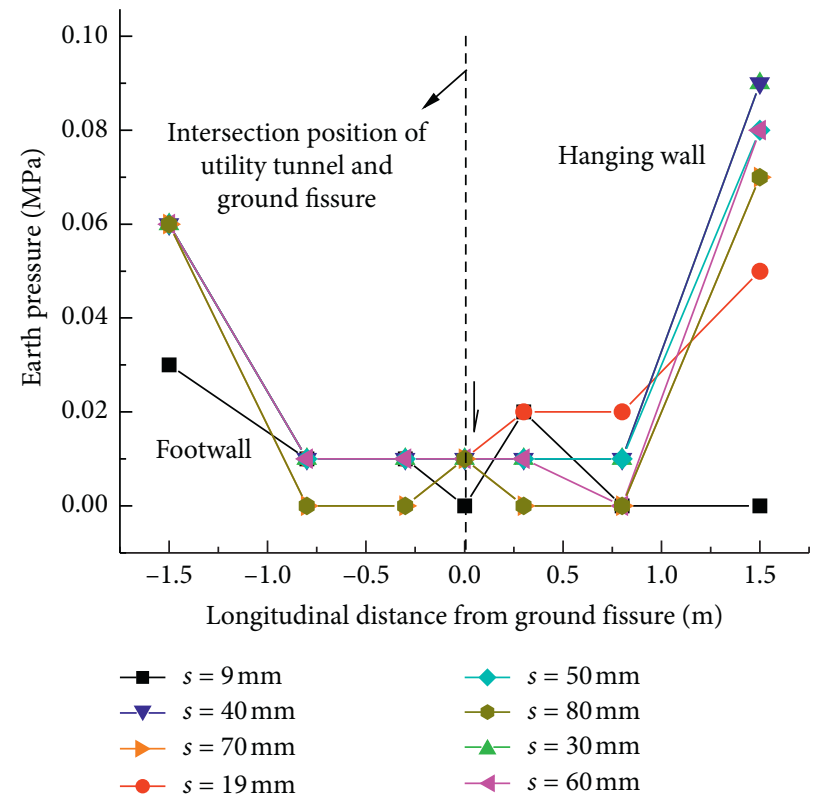

(b)

FIGURE 10: Longitudinal earth pressure curve on top and bottom of structure. (a) Longitudinal earth pressure curve on bottom of structure. (b) Longitudinal earth pressure curve on top of structure.

structure to the footwall is $0.8 \mathrm{~m}$. The axial line at the top of the structure bore the maximum earth pressure. On the hanging wall, the earth pressure increased as ground pressure vertical displacement increased; on the footwall, the earth pressure decreased as ground pressure vertical displacement increased. This is similar to the earth pressure behavior observed at the section from the intersection of the ground fissure and the axis of the utility tunnel structure to the hanging wall (also $0.8 \mathrm{~m}$ ).

Transverse earth pressure variations on the bottom of the structure are shown in Figure 12. In Figure 12(a), the bottom of the structure under earth pressure extends from the intersection of the ground fissure and the axis of the utility tunnel structure to the hanging wall at $0.8 \mathrm{~m}$. Earth pressure increased during the experiment on both the foot and hanging wall. The position of the axis at the top of the structure bore the maximum earth pressure, but the earth pressure on both sides decreased. The torsion of the structure loosened the soil on both sides of the structure.

The earth pressure at the same position at the top of the structure behaved similarly. In Figure 12(b), this section extends from the intersection of the ground fissure and the axis of the utility tunnel structure to the footwall $(0.8 \mathrm{~m})$. The axial line at the bottom of the structure bore the minimum earth pressure. On the footwall, the earth pressure decreased as ground fissure vertical displacement increased. On the 

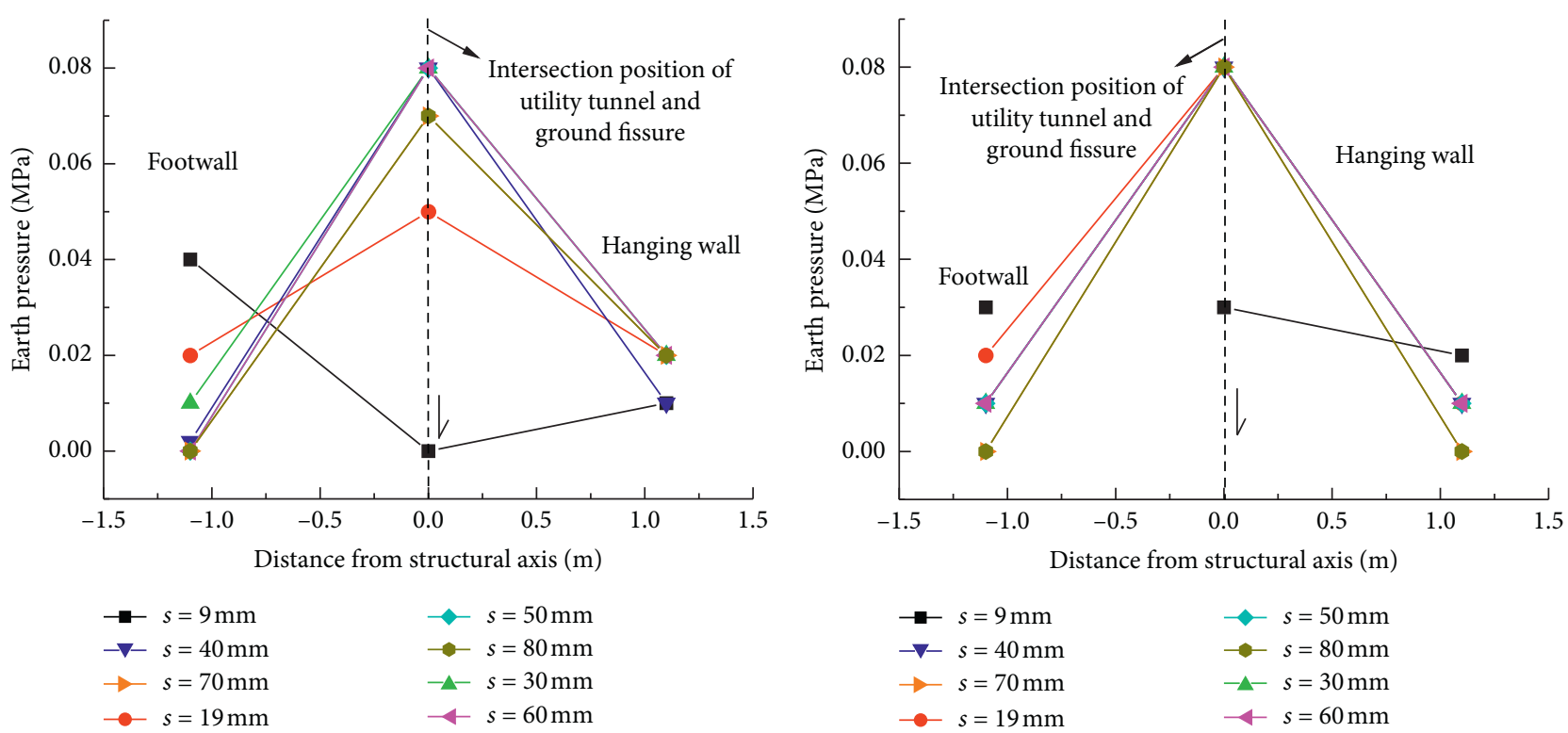

(a)

(b)

Figure 11: Transverse earth pressure curve on top of structure. (a) Transverse earth pressure curve on top of structure from the intersection of the ground fissure and the axis of the utility tunnel structure to the hanging wall at $0.8 \mathrm{~m}$. (b) Transverse earth pressure curve on top of structure from the intersection of the ground fissure and the axis of the utility tunnel structure to the footwall at $0.8 \mathrm{~m}$.

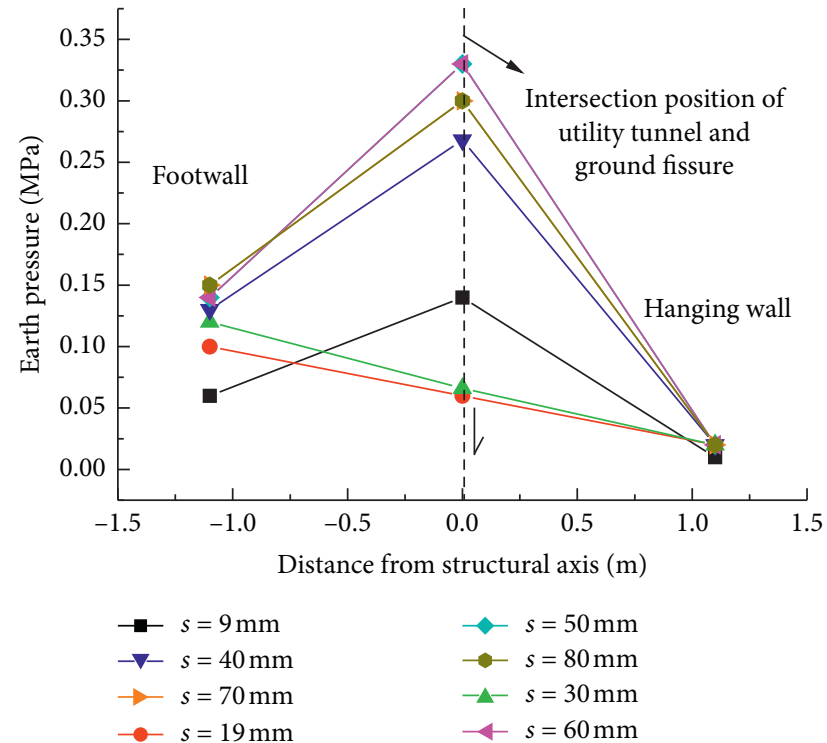

(a)

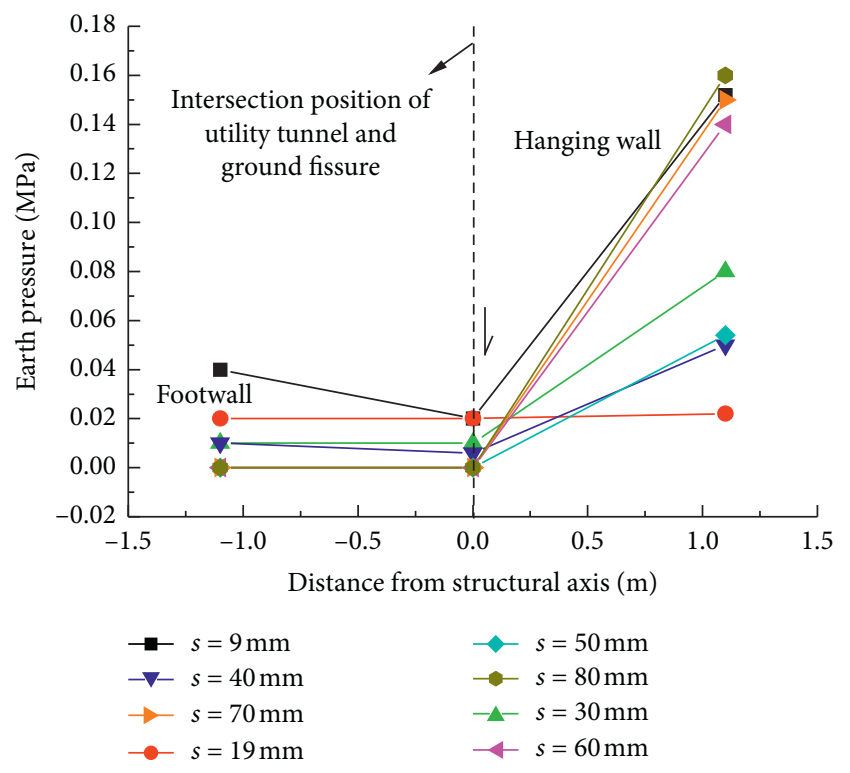

(b)

Figure 12: Transverse earth pressure curve on bottom of structure. (a) Transverse earth pressure curve on bottom of structure, the intersection of the ground fissure and the axis of the utility tunnel structure to the hanging wall at $0.8 \mathrm{~m}$. (b) Transverse earth pressure curve on bottom of structure, the intersection of the ground fissure and the axis of the utility tunnel structure to the footwall at $0.8 \mathrm{~m}$.

hanging wall, the earth pressure first decreased and then increased over the course of the same increase in ground fissure vertical displacement.

3.1.3. Lateral Earth Pressure Variations. As shown in Figure 13(a), the earth pressure on the north side wall of the structure on the hanging and footwall decreased as ground fissure vertical displacement increased. The contact earth pressure between the north side of the structure and the soil reached the maximum value $0.032 \mathrm{MPa}$ at the end of the footwall. The earth pressure at the ground fissure location reached the minimum value $0 \mathrm{MPa}$. Due to the presence of the void area, structure lateral earth pressure formed a 


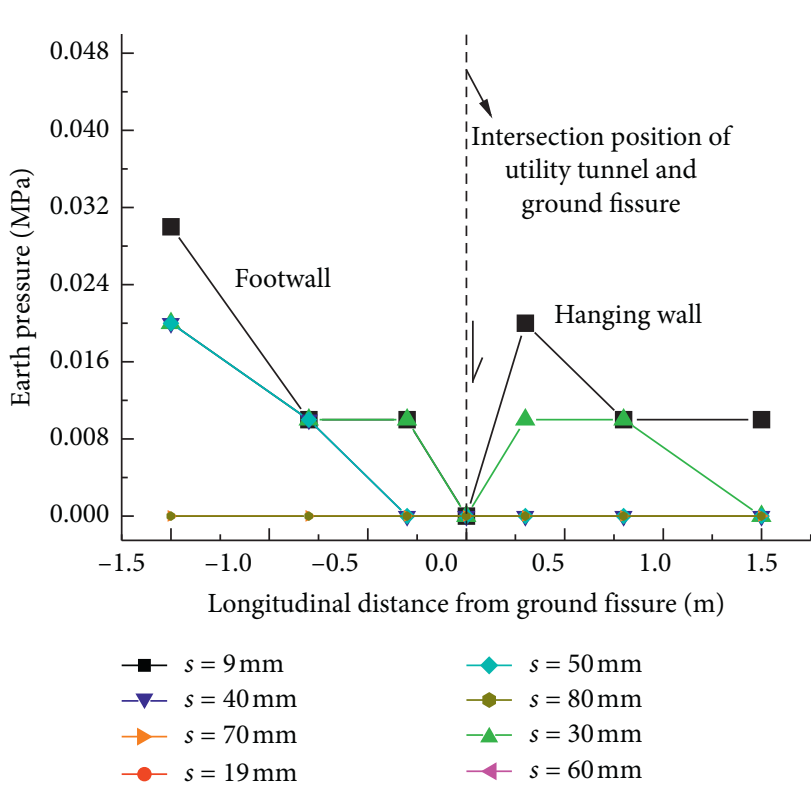

(a)

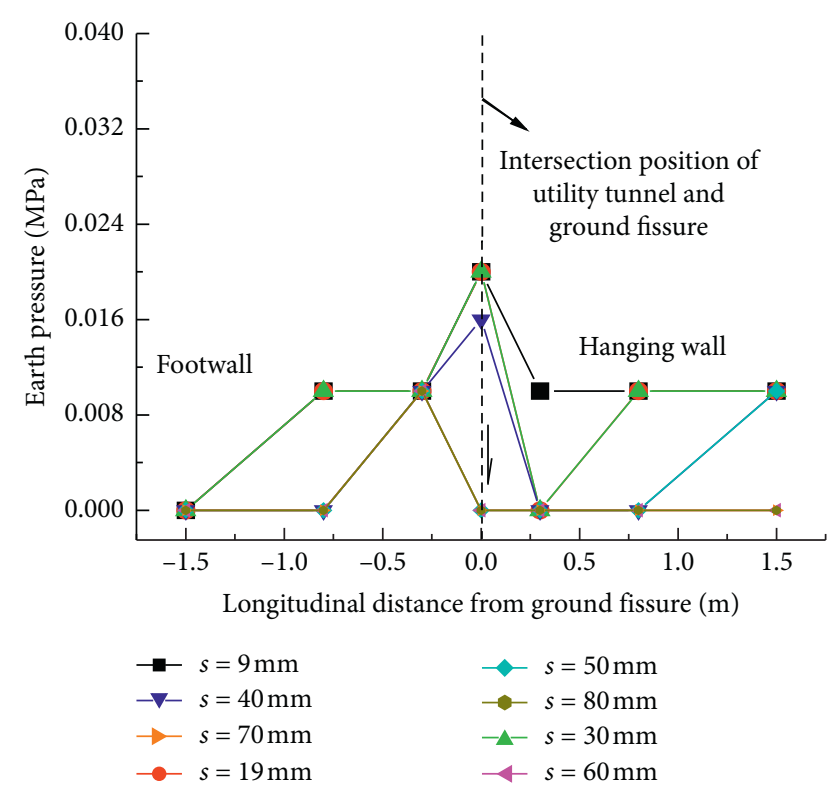

(b)

FIGURE 13: Lateral earth pressure change curve on the north and south. (a) Lateral earth pressure change curve on the north. (b) Lateral earth pressure change curve on the south.

clockwise torque; the structure twisted clockwise and the earth pressure decreased as ground fissure vertical displacement increased.

As shown in Figure 13(b), the contact earth pressure between the south side of the structure and the soil decreased at both the hanging wall and the footwall as ground fissure vertical displacement increased. The earth pressure at the ground fissure location reached the maximum value $0.02 \mathrm{MPa}$; it is very different from the north side of the structure. Except the variation at the ground fissure location, these variations (on the hanging wall and the footwall) in earth pressure are similar to those on the north side of the structure due to the clockwise twist of the structure.

\subsection{Longitudinal Deformation of Steel. Figures 14 and 15} show the strain curves of the longitudinal structure bottom and top steel strain under various dislocations of the ground fissure. In this paper, the strain value is positive in tension and negative in compression. As shown in Figure 14, the bottom of the steel strain along the longitudinal direction at the end of the hanging wall transformed from tension to compression over the course of the experiment; a similar transformation occurred at the end of the footwall and near the ground fissure. Compression strain is generated at the end of the structure located on the footwall. The tensile strain at the footwall of the structure was higher than that at the hanging wall, and at $0.325 \mathrm{~m}$ from the ground fissure to the footwall, the tensile strain maximized.

As shown in Figure 15, the top of the steel strain along the longitudinal direction at the hanging wall and footwall was mainly in a state of tension. When the settlement reached $60 \mathrm{~mm}$, the tensile strain reached yield, as the top of the concrete in the footwall cracked; this is why the

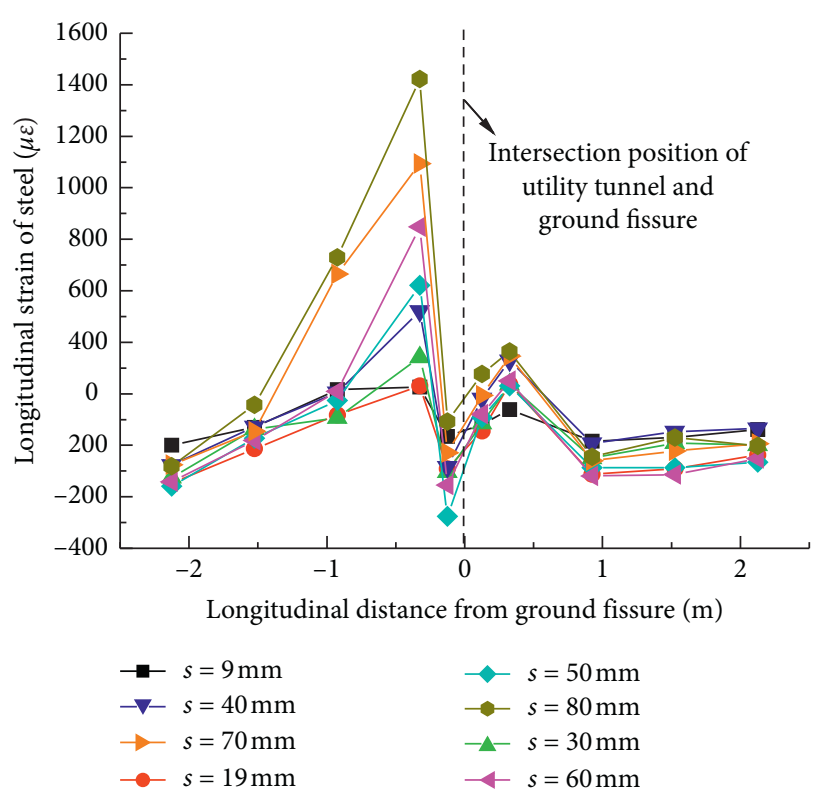

FIGURE 14: Longitudinal strain of bottom reinforcement.

$s=60 \mathrm{~mm}$ curve appears more above than $s=70 \mathrm{~mm}$ and $s=80 \mathrm{~mm}$.

3.3. Longitudinal Deformation of Structure. Figures 16 and 17 show longitudinal strain curves of the top and bottom of the structural concrete surface under various dislocations of the ground fissure. As shown in Figure 16, the compression zone of the structure top was mainly distributed in the footwall; the tension zone of the structure top was mainly distributed in the hanging wall. This is mainly due to the 


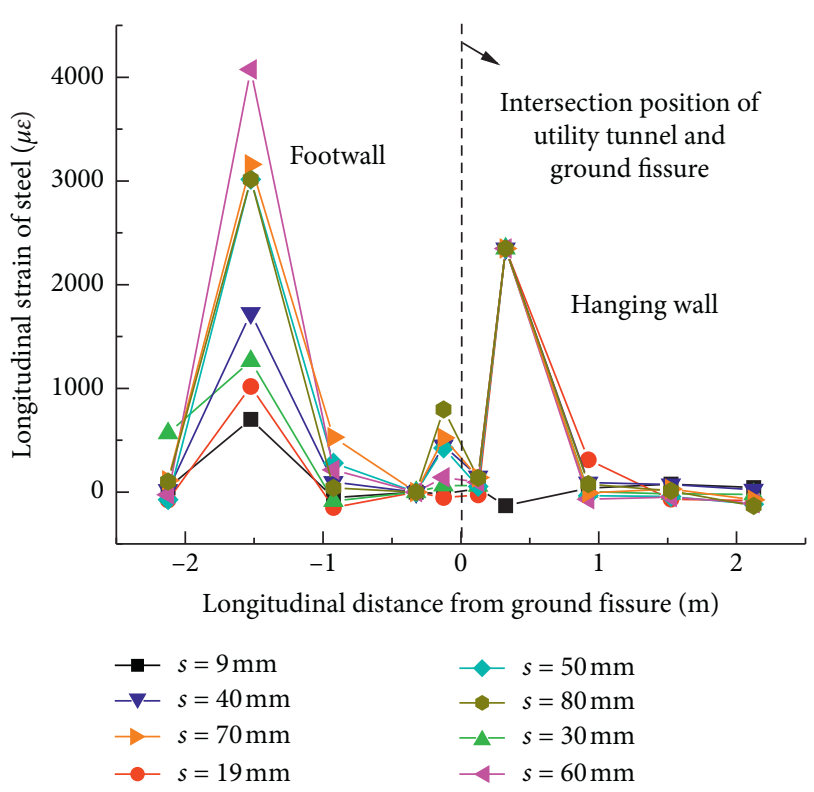

FigURE 15: Longitudinal strain of top reinforcement.

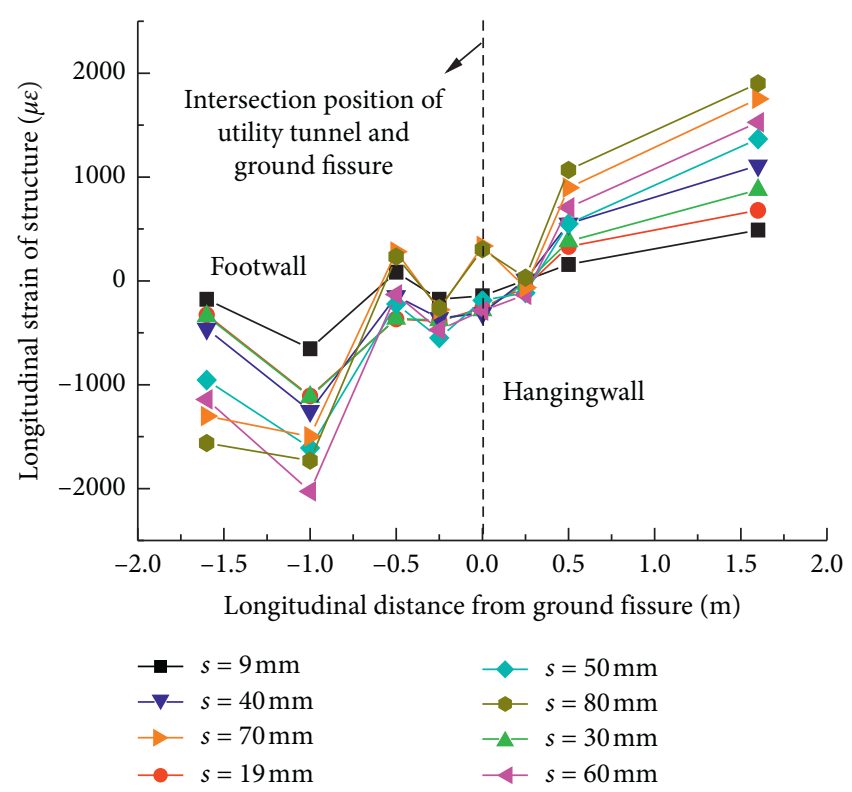

FIgURE 16: Longitudinal strain of top structure.

structure being deformed by torsion. At a distance of $1.0 \mathrm{~m}$ from the ground fissure to the footwall, the compressive strain was concentrated and the concrete reached the yield when the ground fissure settlement reached $60 \mathrm{~mm}$ because the corresponding compressive strain became smaller after settlements of 70 and $80 \mathrm{~mm}$. At the intersection of the structural axis and ground fissure, the strain changed from compression to tension and the force was more complicated.

As shown in Figure 17, the strain in the top of structure was mainly characterized by tension. At a distance of $1.0 \mathrm{~m}$ from the ground fissure to the footwall, the tension strain was concentrated and the concrete reached the yield when

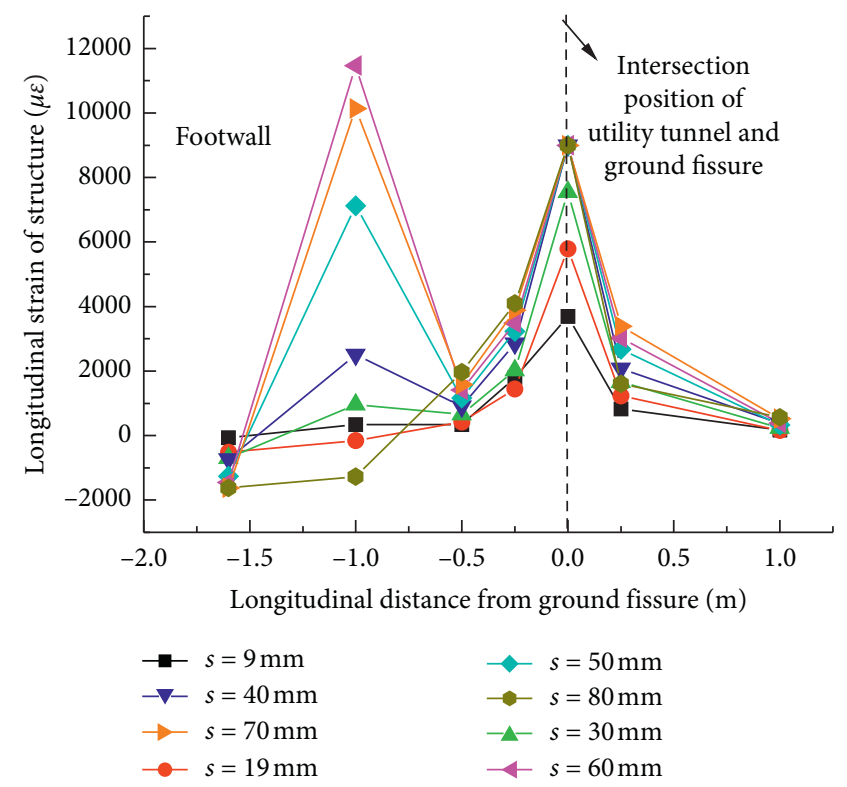

FIgURE 17: Longitudinal strain of bottom structure.

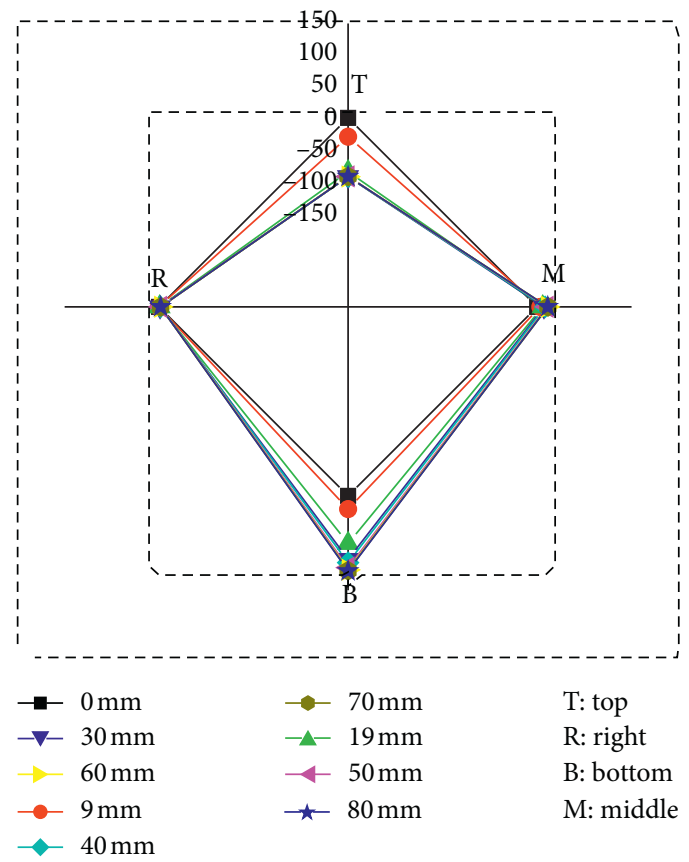

FIGURE 18: Hanging wall cross-sectional cabin 1 displacement.

the ground fissure settlement reached $60 \mathrm{~mm}$ because the corresponding tension strain became smaller after settlements of 70 and $80 \mathrm{~mm}$. When the settlement reached $60 \mathrm{~mm}$, as the top of the concrete cracked in the footwall and the tensile strain was released, this is why the $s=60 \mathrm{~mm}$ curve appears more above than $s=70 \mathrm{~mm}$ and $s=80 \mathrm{~mm}$. This is consistent with the results shown in Figure 15.

3.4. Convergence Deformation Law of Structure. Section 1 convergence deformation is shown in Figures 18 and 19. In 


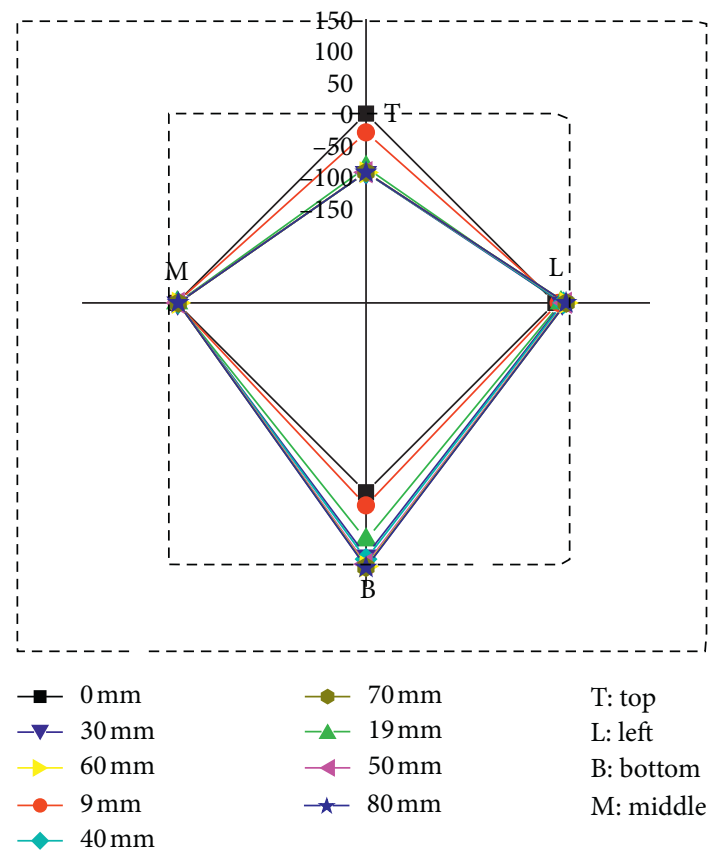

FIGURE 19: Hanging wall cross-sectional cabin 2 displacement.

this paper, the structure is convergence deformation, tension is positive, and compression is negative. As the vertical settlement increased, the displacement of the hanging wall of the utility tunnel changed gradually downward and rightward. The vertical displacement exceeded the rightward displacement and the vertical displacement of cabin 2 was greater than that of cabin 1 . When the ground fissure settlement is from $9 \mathrm{~mm}$ to $19 \mathrm{~mm}$, the cross-sectional displacement increases significantly.

The overall displacement of the structural section is asymmetric.

Section 2 convergence deformation is shown in Figures 20 and 21, where the section is located at the intersection of the ground fissure and the axis of the utility tunnel structure. Cabin 1 is in the footwall and cabin 2 is in the hanging wall. The cross-sectional displacement of the utility tunnel grew asymmetrical as the ground fissure vertical settlement increased; cabin 1 experienced significant upward displacement, while cabin 2 underwent significant downward displacement. The amount of displacement of the two was roughly the same.

Section 3 convergence deformation is shown in Figures 22 and 23. The cross-sectional displacement at the footwall of the utility tunnel was smaller than that of the hanging wall. Cabin 1 underwent upward displacement, while cabin 2 showed no significant changes. Cabin 1 displacement first increased as ground fissure vertical displacement increased. When the settlement of hanging wall is from $19 \mathrm{~mm}$ to $30 \mathrm{~mm}$, the vertical displacement then began to increase consistently with the time and location of cracks on the soil surface.

According to the deformation diagram of each section shown in Figures 18-23, it appears that the utility tunnel twisted in a clockwise direction. This is evident from the

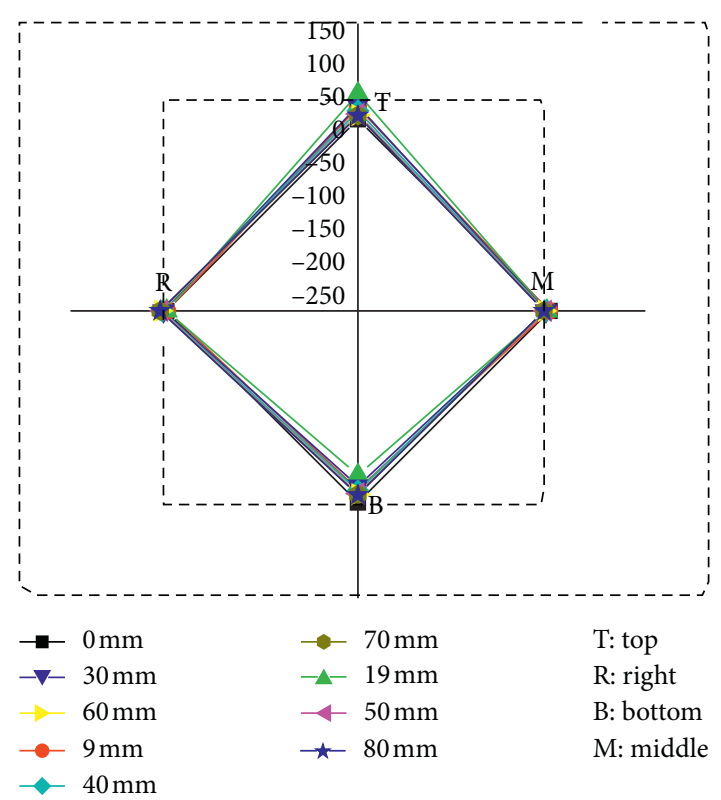

FIGURE 20: Intersection position of structure and ground fissure cabin 1 displacement.

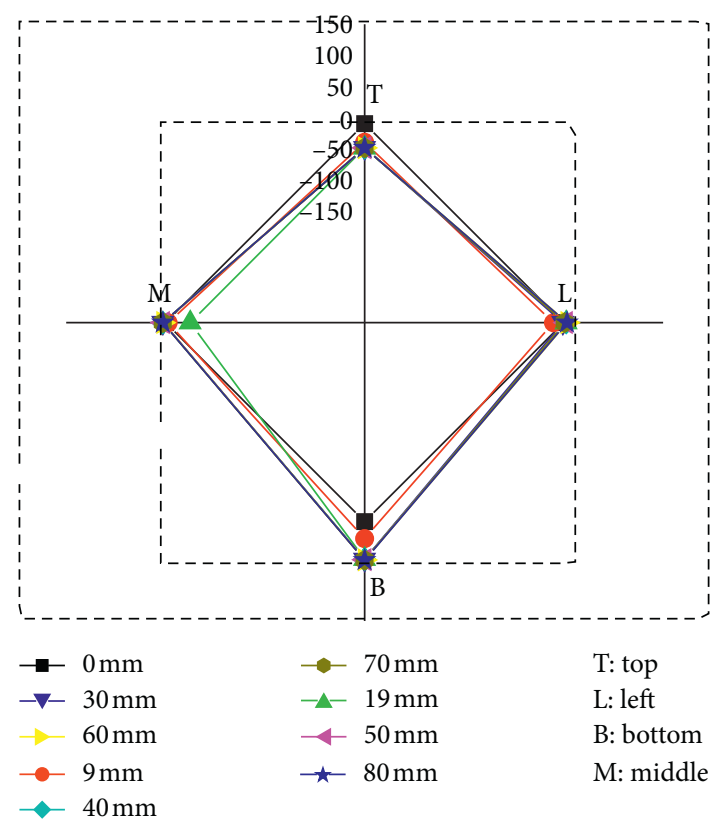

FIgURE 21: Intersection position of structure and ground fissure cabin 2 displacement.

hanging wall to the footwall along the axis of the structure (Figure 24).

The twisting of the structure can be attributed to the presence of a void zone at the bottom of the utility tunnel structure (Figure 25). The overburden soil pressure within the structural void area is equivalent to a concentrated force $P$ (Figure 26). Force $P$ is concentrated on the centroid $O$ of triangle $\mathrm{ABC}$; the centroid of the triangle has an eccentricity $e$ to the axis of the structure, external torque $M=P e$ appears 


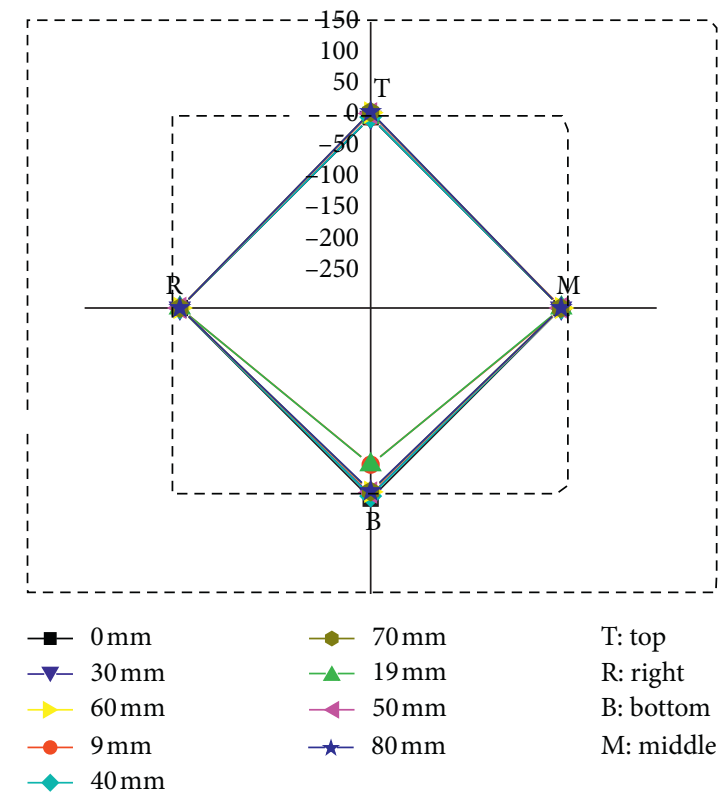

Figure 22: Footwall cross-sectional cabin 1 displacement.

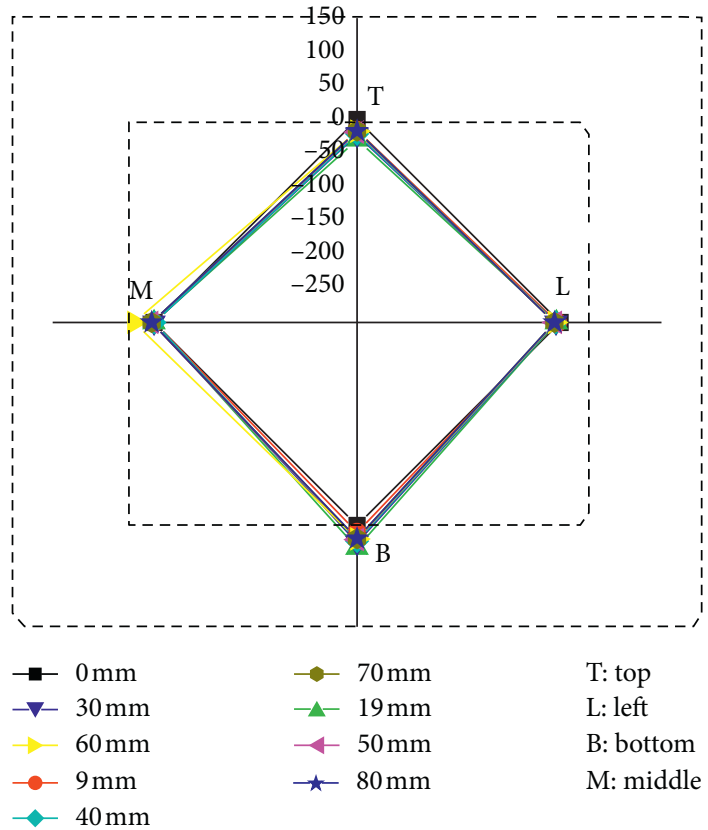

FIgURE 23: Footwall cross-sectional cabin 2 displacement.

near the void area, and the structure twists under the action of torque. The falling of the footwall caused the structure to experience torsional deformation rather than only bending deformation. The circumferential shear flow in this section of the structure also indicates that it twisted clockwise
(Figure 27). However, the direction of the shear stress at some points changed, which indicated that the structural stress field was changing due to the effects of ground fissures, which were similar to previous conclusions of a subway tunnel passing obliquely through a ground fissure [24]. 


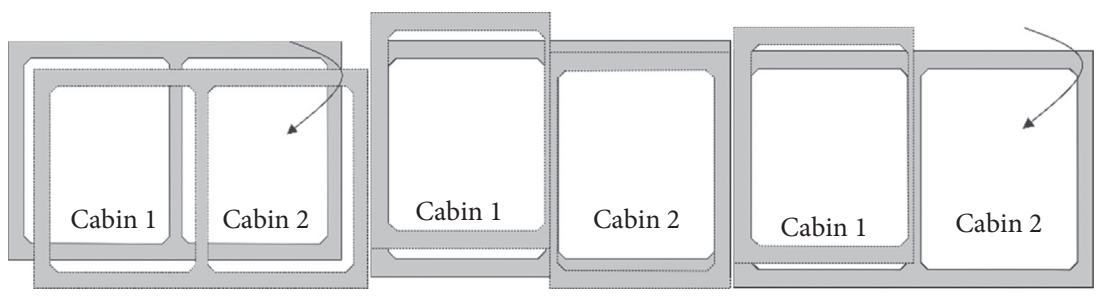

(a)

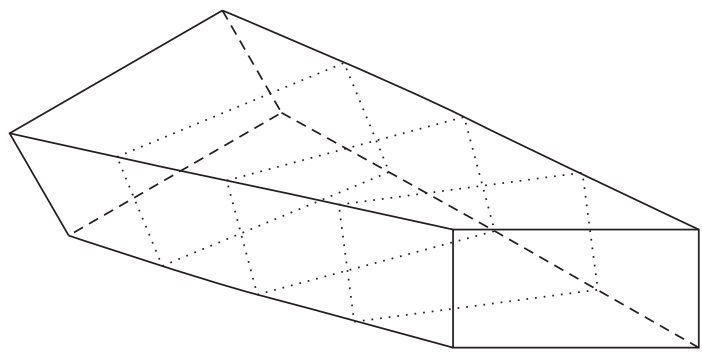

(b)

FIgURE 24: Section torsion diagram.

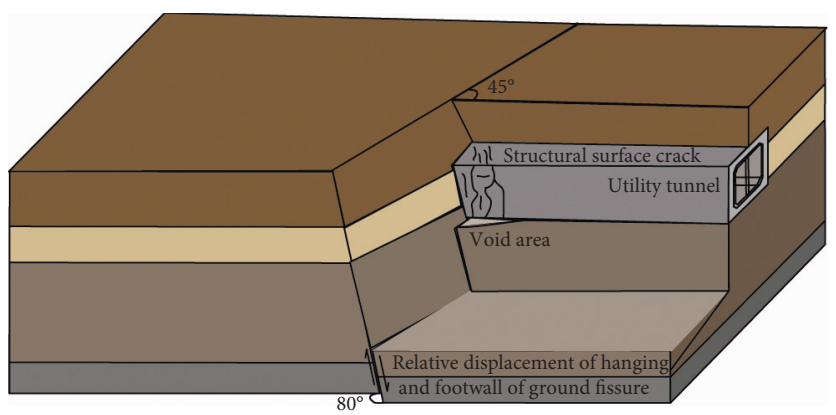

FIGURE 25: Diagram of void area.

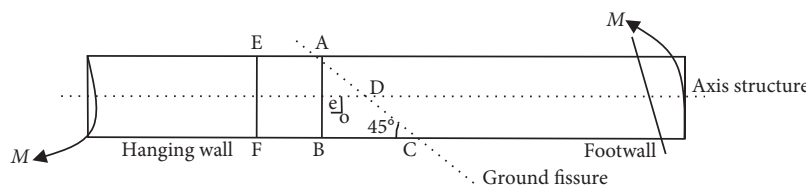

(a)
Earth pressure over the hanging wall structure Earth pressure over the footwall structure

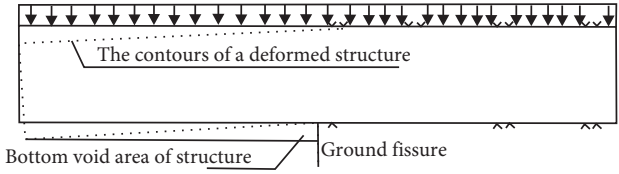

(b)

FIgURE 26: Structural force. (a) Force on the top of the structure. (b) Side force of the structure.

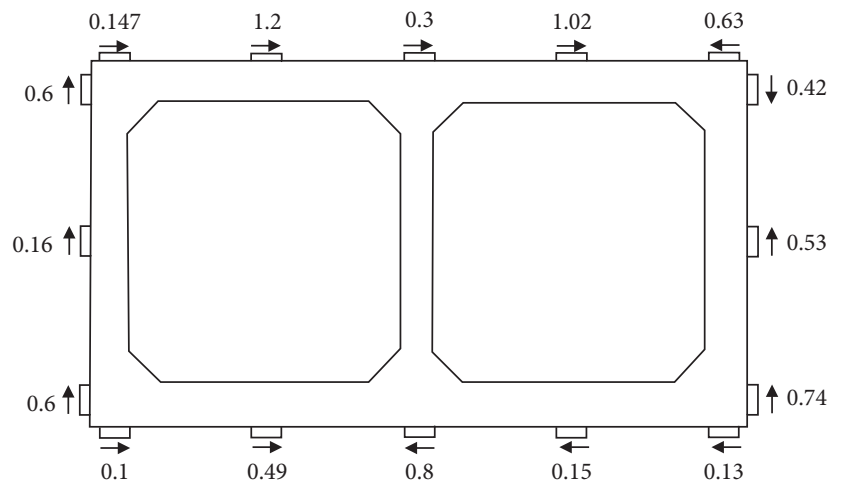

Figure 27: Concrete circumferential shear stress of surface (unit: $\mathrm{MPa})$.

\section{Conclusions}

A model test was performed in this study to assess the mechanical behavior of a utility tunnel crossing a ground fissure. The earth pressure, stress-strain relationship of the structure, and the structural displacement at various locations in the model structure were measured. The conclusions can be summarized as follows.

(1) With increased hanging wall settlement, the vertical contact soil pressure between the soil and structure top showed a significant increase in the hanging wall and significant decrease in the footwall. With increased displacement level, the vertical contact earth pressure between the soil and structure bottom on 
the hanging wall, except for the structure end, decreased significantly to 0 . This was roughly consistent with the scope of the void area at the structure's bottom, which was observed at the test site. The transverse earth pressure at the top of the structure, which is at the position of the structural axis, was larger and significantly increased, with the earth pressure on both sides being smaller, and the earth pressure at the footwall gradually decreased. Also, the earth pressure at the hanging wall did not change much, forming a clockwise torque, and the structure was subject to torsional deformation.

(2) The largest steel strain occurred in the footwall, either at the top or the bottom of the structure. Longitudinal steel strain affects the bottom of the structure not by bending but by torsional deformation. The strain of structural concrete surface reaches its maximum value in the footwall, as does the steel strain.

(3) As per the observable structure displacement, the utility tunnel is twisted clockwise from the hanging wall to the footwall along the axis of the structure.

(4) Based on the analysis of structural strain, earth pressure, and displacement, the structure is not only destroyed by bending deformation but also by torsional deformation. Structural deformation is mainly concentrated in the footwall. It is recommended to tailor structural designs to adapt to the various types of deformation caused by ground fissures, for example, by equipping parts of the structure passing through the ground fissure with flexible joints.

\section{Data Availability}

All data generated or analyzed during this study are included in the article.

\section{Disclosure}

This manuscript is the authors' original work and has not been published nor has it been submitted simultaneously elsewhere.

\section{Conflicts of Interest}

The authors declare that they have no conflicts of interest.

\section{Acknowledgments}

The authors acknowledge the Key Research and Development Program of Shaanxi Province as the work described in this article is part of a research project on the "Seismic Response and Seismic Mitigation Measures for Utility Tunnel Structure under Trans-Ground Fissure" funded by them under Grant no. 2017ZDXM-SF-095. Also, the National Natural Science Foundation of China is acknowledged for funding under Grant no. 41877285 as the work described in this article is part of a research project on the "The Formation Mechanism and Evolution Process of Passive
Soil-Arch Effect in front of Cantilever Rectangular AntiSlide Piles in Loess Area."

\section{References}

[1] T. L. Holzer and, "Ground failure induced by ground-water withdrawal from unconsolidated sediment," in Reviews in Engineering Geology, Geological Society of America, Inc., pp. 67-102, Boulder, CO, USA, 1984.

[2] G.-Y. Wang, G. You, J.-Q. Zhu, J. Yu, and W. Li, "Earth fissures in Su-Xi-Chang region, Jiangsu, China," Surveys in Geophysics, vol. 37, no. 6, pp. 1095-1116, 2016.

[3] J. Peng, J. Qiao, Y. Leng, F. Wang, and S. Xue, "Distribution and mechanism of the ground fissures in wei river basin," the origin of the silk road," Environmental Earth Sciences, vol. 75, no. 8 , p. $718,2016$.

[4] L. Ayalew, H. Yamagishi, and G. Reik, "Ground cracks in Ethiopian rift valley: facts and uncertainties," Engineering Geology, vol. 75, no. 3-4, pp. 309-324, 2004.

[5] C. F. Lee, J. M. Zhang, and Y. X. Zhang, "Evolution and origin of the ground fissures in xian, china," Engineering Geology, vol. 43, pp. 45-55, 1996.

[6] Y. Li, J. Yang, and X. Hu, "Origin of ground fissures in the Shanxi graben system, northern china," Engineering Geology, vol. 55 , no. 4, pp. $267-275,2000$.

[7] E. Rojas, J. Arzate, and M. Arroyo, "A method to predict the group fissuring and faulting caused by regional groundwater decline," Engineering Geology, vol. 65, no. 4, pp. 245-260, 2002.

[8] J. W. Bell, J. G. Price, and M. D. Mifflin, "Subsidence induced fissuring along preexisting faults in Las Vegas Nevada," in Proceedings of the 35th Annual Meeting of the Association of Engineering Geologist, pp. 66-75, Long Beach, CA, USA, October 1992.

[9] J. Pacheco, J. Arzate, E. Rojas, M. Arroyo, V. Yutsis, and G. Ochoa, "Delimitation of ground failure zones due to land subsidence using gravity data and finite element modeling in the Querétaro valley, México," Engineering Geology, vol. 84, no. 3-4, pp. 143-160, 2006.

[10] X. Li, S. J. Wang, T. Y. Liu, and F. S. Ma, "Engineering geology, ground surface movement and fissures induced by underground mining in the Jinchuan nickel mine," Engineering Geology, vol. 76, no. 1-2, pp. 93-107, 2004.

[11] L. D. Filippis, E. Anzalone, A. Billi, C. Faccenna, P. P. Poncia, and P. Sella, "The origin and growth of a recently-active fissure ridge travertine over a seismic fault, Tivoli, Italy," Geomorphology, vol. 195, pp. 13-26, 2013.

[12] T. L. Holzer, "State and local response to damaging land subsidence in United States urban areas," Engineering Geology, vol. 27, no. 1-4, pp. 449-466, 1989.

[13] S. S. El Baruni, "Earth fissures caused by groundwater withdrawal in sarir south agricultural project area, Libya," Hydrogeology Journal, vol. 2, no. 1, pp. 45-52, 1994.

[14] M. A. Laike, "Environmental hazard from fissures in the main Ethiopian rift," Journal of African Earth Sciences, vol. 27, no. 3-4, pp. 481-490, 1998.

[15] F. M. Williams, M. A. J. Williams, and F. Aumento, "Tensional fissures and crustal extension rates in the northern part of the main ethiopian rift," Journal of African Earth Sciences, vol. 38, no. 2, pp. 183-197, 2004.

[16] J.-B. Peng, L.-W. Chen, Q.-B. Huang, Y.-M. Men, W. Fan, and J.-K. Yan, "Physical simulation of ground fissures triggered by underground fault activity," Engineering Geology, vol. 155, pp. 19-30, 2013. 
[17] J.-B. Peng, Q.-B. Huang, Z.-P. Hu et al., "A proposed solution to the ground fissure encountered in urban metro construction in Xi'an, China," Tunnelling and Underground Space Technology, vol. 61, pp. 12-25, 2017.

[18] M. Hernandez-Marin and T. J. Burbey, "Controls on initiation and propagation of pumping-induced earth fissures: insights from numerical simulations," Hydrogeology Journal, vol. 18, no. 8, pp. 1773-1785, 2010.

[19] R. C. Jachens and T. L. Holzer, "Differential compaction mechanism for earth fissures near Casa Grande, Arizona," Geological Society of America Bulletin, vol. 93, no. 10, pp. 998-1012, 1982.

[20] P. B. Burridge, R. F. Scott, and J. F. Hall, "Centrifuge study of faulting effects on tunnel," Journal of Geotechnical Engineering, vol. 115, no. 7, pp. 949-967, 1989.

[21] A. R. Shahidi and M. B. Vafaeian, "Analysis of longitudinal profile of the tunnels in the active faulted zone and designing the flexible lining (for Koo hrang-III tunnel)," Tunneling and Underground Space Technology, vol. 20, no. 3, pp. 213-221, 2005.

[22] J. B. Peng, X. H. Sun, W. Wang, and G. C. Sun, "Characteristics of land subsidence, ground fissures and related disaster chain effects with respect to urban hazards in Xian, China," Environmental Earth Sciences, vol. 75, no. 16, pp. 136-146, 2016.

[23] J. Peng, J. Xu, R. Ma, and F. Wang, "Characteristics and mechanism of the longyao ground fissure on North China plain, China," Engineering Geology, vol. 214, pp. 136-146, 2016.

[24] J. B. Peng, Z. P. Hu, Y. M. Men et al., “Test study of deformation and damage mechanism of horseshoeshaped tunnel crossing ground fissure with $40^{\circ}$," Journal of Rock Mechanics and Engineering, vol. 28, no. 11, pp. 2258-2265, 2009.

[25] Q. B. Huang, J. B. Peng, Y. M. Men et al., "Model test study on effect of ground fissure on open-cut metro tunnel with integral lining," Journal of Rock Mechanics and Engineering, vol. 27, no. 11, pp. 2324-2331, 2008.

[26] W. Fan, L. S. Deng, J. B. Peng et al., "Study of the physical model experiment of subway tunnel crossing the ground fissure belt," Chinese Journal of Rock Mechanics and Engineering, vol. 27, no. 9, pp. 1917-1923, 2008.

[27] Z. P. Hu, J. B. Peng, Q. B. Huang et al., "Physical model test of box tunnel crossing active ground fissure with $30^{\circ}$," Journal of the Railway, vol. 33, no. 04, pp. 105-111, 2011.

[28] J. Yang, Similarity Theory and Construction Model Experiment, Wuhan University of Technology Press, Wuhan, China, 2005.

[29] Q. B. Huang, J. B. Peng, H. Fan et al., "Metro tunnel hazards induced by active ground fissures in Xi'an and relevant control measures," Geotechnical Engineering, vol. 31, no. 5, pp. 781-788, 2009. 